ISSN 0258-7122 (Print), 2408-8293 (Online)

Bangladesh J. Agril. Res. 42(4): 725-730, December 2017

\title{
EFFICACY OF INSECTICIDES FOR SUPPRESSING POD BORER OF MUNGBEAN
}

\author{
M. SHAHIDUZZAMAN ${ }^{1}$, B. L. NAG ${ }^{2}$, H. M. K. BASHAR ${ }^{3}$ \\ AND G. N. HASAN ${ }^{4}$
}

\begin{abstract}
A field experiment was carried out at Regional Pulses Research Station (RPRS), Madaripur during Kharif-I season of 2014 and 2015 to find out the effective insecticides for suppressing pod borer (Helicoverpa armigera Hubner) (Lepidopetera: Noctuidae) infesting Mungbean. In Kharif-I, 2014, suppression of pod borer infestation was the highest $(80.82 \%)$ in Tracer (Spinosad) treated plot and produced the highest (1738 $\left.\mathrm{kg}^{-1} \mathrm{ha}\right)$ seed yield and the highest benefit cost ratio (6.28) obtained in Volium Flexi 300SC (Thiamethaxam+ Chlorantraniliprole) treated plot. In Kharif-I, 2015, suppression of pod borer infestation was the highest (64.15\%) in Volium Flexi 300SC treated plot and produced the highest $\left(1610 \mathrm{~kg}^{-1} \mathrm{ha}\right)$ seed yield and also gave the highest benefit cost ratio (4.27). Considering the two years data the treatment Volium Flexi $300 \mathrm{SC}$ was found to be the best to suppress pod borer attacking mungbean.
\end{abstract}

Keywords: Insecticides, pod borer, mungbean

\section{Introduction}

Mungbean (Vigna radiata L.) is one of the important pulse crops in Bangladesh. Farmers become more interested to cultivate this short duration valuable pulse crop after harvesting of rabi crops (Kharif-I). More than twelve species of insect pests were found to infest mungbean in the field in Bangladesh (Rahman et al. 2000). Among them, pod borer (Helicoverpa armigera Hubner) (Lepidopetera: Noctuidae) is the major insect pest causing considerable losses (Rahman et al., 1981; Bakr 1998; Rahman et al., 2000; Hossain et al., 2004). Pod borer damages flower, flower buds and developing or mature pods (Poehlman, 1991). Pod borer alone has been reported to cause grain yield loss of $136 \mathrm{~kg} / \mathrm{ha}$ (BARI, 1986). Generally farmers spray insecticides to manage pod borers. They use insecticides haphazardly without practicing the actual dose. Sufficient informations regarding insecticidal management practices to suppress pod borer in mungbean are not available. Therefore, the experiment was undertaken to find out the effective and suitable insecticide for suppressing pod borer.

\section{Materials and Methods}

The experiment was conducted at Regional Pulses Research Station (RPRS), Madaripur during Kharif-I season of 2014 and 2015. The land was well ploughed

${ }^{1}$ Scientific Officer, ${ }^{2}$ Chief Scientific Officer, Regional Pulses Research Station, Bangladesh Agricultural Research Institute (BARI), Madaripur, ${ }^{3}$ Senior Scientific Officer, OFRD, Gopalganj, ${ }^{4}$ Scientific Officer, OFRD, Patuakhali, Bangladesh. 
by tractor and leveled. Weeds and stubbles were removed from the field. NPK fertilizers@20-40-20 kg/ha in the form of urea, triple super phosphate and muriate of potash, respectively were applied at final land preparation. The experiment was laid out in Randomized Complete Block Design (RCBD) with three replications. There were five treatments of insecticides viz., Admire 200SL (Imidacloprid) with concentration $0.05 \%$, Belt $24 \mathrm{WG}$ (Flubendiamide) with conentration $0.04 \%$, Tracer 45SC (Spinosad) with concentration $0.04 \%$, Volium Flexi 300SC (Thiamethaxam+Chlorantraniliprole) with concentration $0.05 \%$, Proclaim 5SG (Emamectin Benzoate) with concentration $0.1 \%$ and untreated control was used in the trial. The seeds of BARI Mung- 6 were sown on 05 March, 2014 and 04 March, 2015 in rows with the spacing of $40 \mathrm{~cm}$. The populations of plants were maintained constant by keeping plant to plant distance $7 \mathrm{~cm}$. The experiment was monitored regularly to observe the onset of insect. Insecticidal treatments were sprayed from the first appearance (flowering stage) of the insects. Intercultural operations were done whenever necessary. Total three sprays were applied at intervals of 7 days with the knapsack sprayer. Cost of fungicides application was calculated in per hectare adding labour cost to find out benefit cost ratio.

At maturity, all the pods were collected from 10 randomly selected plants from central four rows of each plot and examined. The infested (bored) and total pods of each plant were counted and the percent pod infestation was calculated.

The pods of each plot were harvested and threshed. The grains were cleaned and dried in the bright sun. The grain yield obtained from each plot was converted into $\mathrm{kg}$ per hectare. The experimental data were analyzed by MSTAT-C software. The percent data were transformed by square root transformation for statistical analysis. The grain yield loss per hectare due to pod borer infestation of each treatment was calculated using a standard formula based on percent pod infestation of actual yield obtained and expected yield in absence of any pod borer infestation for the respective treatment (Hossain et al., 2004). Yield loss of mungbean due to pod borer $=\mathrm{Ye}-\mathrm{Ya}$, where $\mathrm{Ya}=$ Actual yield $\left(\mathrm{kgha}^{-1}\right)$ and $\mathrm{Ye}=$ Expected yield in absence of any infestation.

$\mathrm{Ye}=\frac{\operatorname{YaX} 100}{100-P}$, where $\mathrm{P}=$ Percent pod infestation.

Treatment mean were compared using Duncan's Multiple Range Test. The marginal benefit cost ratio (MBCR) was calculated on the basis of prevailing market price of mungbean, insecticides and spraying cost. Marginal benefit cost ratio was calculated as follows:

$$
\mathrm{MBCR}=\frac{\text { Benefit over control }}{\text { Cost of treatment }}
$$




\section{Results and Discussion}

The larvae of pod borer consumed seed of mungbean when the pod developed and a single borer damaged more than one pods voraciously. The damaged pods showed hole and resulted reduced yield. Insecticides application significantly suppressed pod borer infestation over untreated control in both the cropping seasons (Table 1).

During Kharif-I 2014, the lowest (4.17\%) pod borer infestation was observed in Tracer 45SC treated plot which was statistically identical to that of Volium Flexi 300SC and Admire 200SL treated plot. The highest (21.74\%) pod borer infestation was found in untreated control plot. Pod borer infestation reduction over control ranged from $45.63-80.82 \%$. Reduction of pod infestation was the highest $(80.82 \%)$ in Tracer 45SC sprayed plots followed by $(69.55 \%)$ Volium Flexi 300SC treated plot which was very close to Admire 200SL (68.49\%) treated plot. The lowest $(45.63 \%)$ pod infestation reduction over control was found in Belt 24WG treated plot. In this cropping season, highest yield loss (314 $\mathrm{kg}^{-1} \mathrm{ha}$ ) obtained from untreated control and the lowest yield loss $\left(76 \mathrm{~kg}^{-1} \mathrm{ha}\right)$ was found in Tracer 45SC treated plot.

Table 1. Effect of Insecticide treatments on the pod infestation by pod borer and yield loss of mungbean during Kharif-I 2014 and 2015

\begin{tabular}{|c|c|c|c|c|c|c|}
\hline \multirow{2}{*}{ Treatments } & \multicolumn{2}{|c|}{ Pod infestation (\%) } & \multicolumn{2}{|c|}{$\begin{array}{c}\text { Infestation reduction over } \\
\text { control }(\%)\end{array}$} & \multicolumn{2}{|c|}{ Yield loss $\left(\mathrm{kg}^{-1} \mathrm{ha}\right)$} \\
\hline & $\begin{array}{l}\text { Khrif-I, } \\
2014\end{array}$ & $\begin{array}{l}\text { Khrif-I, } \\
2015\end{array}$ & $\begin{array}{l}\text { Khrif-I, } \\
2014\end{array}$ & Khrif-I, 2015 & $\begin{array}{c}\text { Khrif-I, } \\
2014\end{array}$ & $\begin{array}{l}\text { Khrif-I, } \\
2015\end{array}$ \\
\hline $\begin{array}{l}\text { Admire 200SL } \\
\text { (Imidacloprid) }\end{array}$ & $\begin{array}{l}6.85 \mathrm{c} \\
(2.62)\end{array}$ & $\begin{array}{l}4.36 \mathrm{~b} \\
(2.09)\end{array}$ & 68.49 & 56.70 & 112 & 65 \\
\hline $\begin{array}{c}\text { Belt } 24 \mathrm{WG} \\
\text { (Flubendiamide) }\end{array}$ & $\begin{array}{l}11.82 \mathrm{~b} \\
(3.44)\end{array}$ & $\begin{array}{l}5.02 \mathrm{~b} \\
(2.24)\end{array}$ & 45.63 & 50.15 & 232 & 74 \\
\hline $\begin{array}{r}\text { Tracer45SC } \\
\text { (Spinosad) }\end{array}$ & $\begin{array}{l}4.17 \mathrm{c} \\
(2.04)\end{array}$ & $\begin{array}{l}5.09 \mathrm{~b} \\
(2.26)\end{array}$ & 80.82 & 49.45 & 76 & 78 \\
\hline $\begin{array}{c}\text { Volium Flexi } \\
\text { 300SC } \\
\text { (Thiamethaxam+ } \\
\text { Chlorantraniliprole) }\end{array}$ & $\begin{array}{l}6.62 \mathrm{c} \\
(2.57)\end{array}$ & $\begin{array}{l}3.61 \mathrm{~b} \\
(1.90)\end{array}$ & 69.55 & 64.15 & 115 & 60 \\
\hline $\begin{array}{c}\text { Proclaim 5SG } \\
\text { (Emamectin } \\
\text { Benzoate) }\end{array}$ & $\begin{array}{l}11.01 \mathrm{~b} \\
(3.32)\end{array}$ & $\begin{array}{l}4.27 \mathrm{~b} \\
(2.07)\end{array}$ & 49.36 & 57.60 & 180 & 62 \\
\hline Control & $\begin{array}{l}21.74 \mathrm{a} \\
(4.66)\end{array}$ & $\begin{array}{l}10.07 \mathrm{a} \\
(3.17)\end{array}$ & - & - & 314 & 133 \\
\hline
\end{tabular}

Values within a column having same letter(s) do not differ significantly $(\mathrm{p}=0.05)$

Figures in the parentheses are the square root transformation of values 
During Kharif-I 2015, the infestation of pod borer was comparatively lower than the previous year which might be due to their lower abundance (Table 1). The lowest $(3.61 \%)$ pod infestation was observed in Volium Flexi 300SC treated plot which was statistically similar to that of all the treatments except untreated control. The highest $(10.07 \%)$ pod infestation was found in untreated control plot. Pod borer infestation reduction over control ranged from 49.45-64.15\%. It was observed that pod infestation reduction over control was higher $(64.15 \%)$ in Volium Flexi 300SC sprayed plot followed by $(57.60 \%)$ Proclaim 5SG treated plot which was very close to Admire 200SL (56.70\%) treated plot. The lowest (49.45\%) pod infestation reduction over control was found in Tracer 45SC sprayed plot which was very close to Belt $24 \mathrm{WG}$ (50.15\%). In this year, highest yield loss $\left(133 \mathrm{~kg}^{-1} \mathrm{ha}\right)$ was obtained from untreated control and lowest yield loss $\left(60 \mathrm{~kg}^{-1}\right.$ ha) found in Volium Flexi 300SC treated plot which was comparable to Proclaim 5SG treated plot $\left(62 \mathrm{~kg}^{-1} \mathrm{ha}\right)$.

Table 2. Effect of insecticides on yield, net return and benefit cost ratio in mungbean production during Kharif-1, 2014 and 2015

\begin{tabular}{|c|c|c|c|c|c|c|c|c|c|c|c|c|}
\hline \multirow[t]{2}{*}{ Treatments } & \multicolumn{2}{|c|}{$\begin{array}{l}\text { Yield } \\
\left(\mathrm{kg}^{-1} \mathrm{ha}\right)\end{array}$} & \multicolumn{2}{|c|}{\begin{tabular}{|} 
Additional \\
yield \\
over \\
control \\
$\left(\mathrm{kg}^{-1} \mathrm{ha}\right)$
\end{tabular}} & \multicolumn{2}{|c|}{$\begin{array}{l}\text { Additional } \\
\text { income } \\
\text { over control } \\
\left(\mathrm{Tk}^{-1} \mathrm{ha}\right)\end{array}$} & \multicolumn{2}{|c|}{$\begin{array}{l}\text { Cost of } \\
\text { fungicides } \\
\text { Application } \\
\left(\mathrm{Tk}^{-1} \mathrm{ha}\right)\end{array}$} & \multicolumn{2}{|c|}{$\begin{array}{l}\text { Net income } \\
\left(\mathrm{Tk}^{-1} \mathrm{ha}\right)\end{array}$} & \multicolumn{2}{|c|}{$\begin{array}{l}\text { Marginal } \\
\text { Benefit } \\
\text { cost ratio } \\
\text { (MBCR) }\end{array}$} \\
\hline & 密 & 密的 & 焉 & 密的 & 首 & 岂装 & 节 & 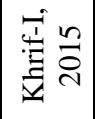 & 密 & 急哭 & 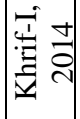 & 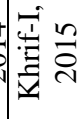 \\
\hline $\begin{array}{l}\text { Admire 200SL } \\
\text { (Imidacloprid) }\end{array}$ & $1520 \mathrm{c}$ & $1420 \mathrm{~b}$ & 390 & 230 & 31200 & 18400 & 7350 & 7350 & 23850 & 11050 & 3.24 & 1.50 \\
\hline $\begin{array}{c}\text { Belt } 24 \text { WG } \\
\text { (Flubendiamide) }\end{array}$ & $1728 \mathrm{a}$ & $1400 \mathrm{~b}$ & 598 & 210 & 47840 & 16800 & 7200 & 7200 & 40640 & 9600 & 5.64 & 1.33 \\
\hline $\begin{array}{c}\text { Tracer 45SC } \\
\text { (Spinosad) }\end{array}$ & $1738 \mathrm{a}$ & $1450 \mathrm{~b}$ & 608 & 260 & 48640 & 20800 & 17640 & 17640 & 31000 & 3160 & 1.76 & 0.18 \\
\hline $\begin{array}{c}\text { Volium Flexi } \\
\text { 300SC } \\
\text { (Thiamethaxam }+ \\
\text { Chlorantraniliprole) }\end{array}$ & $1710 \mathrm{a}$ & $1610 a$ & 580 & 420 & 46400 & 33600 & 6375 & 6375 & 40025 & 27225 & 6.28 & 4.27 \\
\hline $\begin{array}{l}\text { Proclaim 5SG } \\
\text { (Emamectin } \\
\text { Benzoate ) }\end{array}$ & $1455 d$ & $1390 \mathrm{~b}$ & 325 & 200 & 26000 & 16000 & 10050 & 10050 & 15950 & 5950 & 1.59 & 0.59 \\
\hline Control & $1130 \mathrm{e}$ & $1190 \mathrm{c}$ & - & - & - & - & - & - & - & - & - & - \\
\hline
\end{tabular}

Values within a column having same letter(s) do not differ significantly ( $\mathrm{p}=0.05)$

For calculating net return and benefit the following market prices were used:

Admire 200SL (Imidacloprid) $=$ Tk.1850/250ml, Belt 24 WG (Flubendiamide) $=$ Tk.1800/200gm, Tracer45SC (Spinosad) $=$ Tk.5280/200ml, Volium Flexi 300SC $($ Thiamethaxam+Chlorantraniliprole $)=T$ Tk.1525/250ml, Proclaim 5SG (Emamectin Benzoate $=$ Tk.2750/500g, Mungbean $=$ Tk. $80^{-1} \mathrm{~kg}$ and Labour wage $=\mathrm{Tk}$. $300 /$ day/labourer (8 hours day) 
The yields of different treatments are presented in Table 2. The yield of mungbean varied significantly with crop growth, pod setting, pod borer infestation and climatic variation of the cropping seasons. During Kharif-I, 2014, the highest (1738 $\mathrm{kg}^{-1} \mathrm{ha}$ ) yield was obtained from the plot sprayed with Tracer45SC which was statistically identical to that of Belt $24 \mathrm{WG}\left(1728 \mathrm{~kg}^{-1} \mathrm{ha}\right)$ and Volium Flexi 300SC (1710 kg-1 ha) treated plot. The lowest (1130 kg-1 ha) yield was obtained from untreated control plot. The net income and marginal benefit cost ratio varied depending on cost of insecticidal application. In this year, the highest net income (40640 Tk ${ }^{-1}$ ha) was gained from Belt $24 \mathrm{WG}$ treated plot followed by (40025 $\mathrm{Tk}^{-1}$ ha) Volium Flexi 300SC treated plot. The lowest net income (15950 $\mathrm{Tk}^{-1} \mathrm{ha}$ ) obtained from Proclaim 5SG treated plot. The highest benefit cost ratio (6.28) achieved from Volium Flexi 300SC treated plot followed by Belt 24 WG treated plot (5.64). The lowest benefit cost ratio (1.59) was calculated in Proclaim 5SG treated plot. Though the highest net income achieved from Belt $24 \mathrm{WG}$ treated plot, due to lower market price, Volium Flexi 300SC gave higher benefit cost ratio.

During Kharif-1 2015, the highest (1610 kg-1 ha) yield was obtained from the plot sprayed with Volium Flexi 300SC which was statistically significant from all other treatments. The next highest $\left(1450 \mathrm{~kg}^{-1} \mathrm{ha}\right)$ yield was obtained from Tracer45SC treated plot. The lowest $\left(1190 \mathrm{~kg}^{-1} \mathrm{ha}\right)$ yield was found from untreated control plot. Plots treated with Admire 200SL, Belt 24 WG, Tracer45SC and Proclaim 5SG produced statistically identical yield as well as pod infestation (\%). In this year, the highest net income $\left(27225 \mathrm{Tk}^{-1} \mathrm{ha}\right)$ obtained from Volium Flexi 300SC treated plot followed by (11050 $\mathrm{Tk}^{-1}$ ha) Admire 200SL treated plot. The lowest net income (3160 Tk $\mathrm{Tk}^{-1}$ ha) obtained from Tracer45SC treated plot. The highest benefit cost ratio (4.27) achieved from Volium Flexi 300SC treated plot followed by (1.50) Admire 200SL treated plot. The lowest benefit cost ratio (0.18) obtained in Tracer45SC treated plot. Though Tracer45SC sprayed plot provided considerable yield $\left(1450 \mathrm{~kg}^{-1} \mathrm{ha}\right)$, due to higher price of the insecticides it gave lower benefit cost ratio (0.18). Chaudhary and Sachan (1995), Hossain (2012) showed the significant effect of Cypermethrin application on pod borer population reduction compared to untreated control. Giraddi et al. (1994) reported effective control by Endosulfun when 2 sprays were applied at 50\% flowering followed by 2 sprays at the green pod stage.

\section{Conclusion}

From the previous two years findings, it could be concluded that the insecticide Volium Flexi 300SC could suppress pod borer (\% decrease of Pod infestation over control 69.55 and 64.15, respectively) of Mungbean and gave better yield (1710 and $1610 \mathrm{~kg}^{-1}$ ha respectively). So, it may be recommended that from the first appearance of pod borer, three sprays of Volium Flexi 300SC with 
concentration $0.05 \%$ at 7 days interval is applicable for controlling the infestation of pod borer in mungbean.

\section{References}

Bakr, M.A. 1998. Disease and insect management of mungbean and blackgram. Resource manual-Location specific technologies for rice based cropping systems under irrigated conditions. Thana cereal technology transfer and identification project, Dhaka. Pp. 201-205

BARI, 1986. Annual report of pulse improvement programme. 1985-86. Bangladesh Agricultural Research Institute (BARI), Jaydebpur, Gazipur, Bangladesh

Chaudhary, R.R.P. and R.B. Sachan. 1995. Comparative efficacy and economics of some insecticides against gram pod borer, Heliothis armigera (Hubner) in chickpea in western plain of Uttor Pradesh. Bharatiya Krishi Anusandhan Patrika. 10(4): 159164.

Giraddi, R.S., B.S. Goudreddy and P.B. Patil. 1994. Critical time of spray in chickpea for the control of gram pod borer, Helicverpa armigera (Hubner). Karnataka J. Agril. Sci. 7(1): 79-81.

Hossain, M.A. 2012. Development of insectide based management package against insect pests complex of mungbean. Annual Research Report under ACIAR Project, PRC, BARI, Ishwardi, Pabna.

Hossain, M.A., J. Ferdous, M.A. Sarkar and M.A. Rahman. 2004. Insecticidal management of thrips and pod borer in mungbean. Bangladesh J. Agril. Res. 29(3), 347-356.

Poehlman, J.M. 1991. The Mungbean. Oxford and IBH Publ. Co. Pvt. Ltd., New Delhi, Bombay and Calcutta, $292 \mathrm{Pp}$.

Rahman, M.M., M.A. Bakr, M.F. Mia, K.M. Idris, C.L.L. Gowda, J. Kuma, U.K. Dev, M.A. Malek and A. Sobhan. 2000. Legumes in Bangladesh. In: Johansen, C., Duxbury, J. M., Virmani, S. M., Gowda, C. L. L., Pande, S. and Joshi, P. K. (eds.). Legumes in rice and wheat cropping systems of the Indo-Gangetic Plain- Constraints and opportunities. Pathancheru 502 324, Andhra Pradesh, India: ICRISAT and Ithaca, New York, USA: Cornell University. $230 \mathrm{Pp}$.

Rahman, M.M., M.A. Mannan and M.A. Islam. 1981. Pest survey of major summer and winter pulses in Bangladesh. In the Proceedings of the National Workshop on pulses. (eds.) A. K. Kaul. Pp. 265-273. 